\title{
BETWEEN LITERACY AND IDENTITY: FROM LIM KIM HOK AND KHO PING HO TO THE CONTEMPORARY INDONESIAN LITERATURE
}

\author{
Zulfikar RH Pohan \\ (Sekolah Tinggi Ilmu Tarbiyah Hamzah Fansuri, Kota Subulussalam \\ zulfikarriza@mail.ugm.ac.id
}

\begin{abstract}
The history and progress of Indonesian literature become a piece of authentic evidence for ethnic Chinese. Both of them can exert influence on contemporary Indonesian literature at large. It can be seen in the history of Indonesian literacy, romance, martial arts stories (Cerita silat), and Chinese literary writing styles which are still used nowadays. This shows how ethnic Chinese education and Hybrid (Malay-Chinese) in Indonesia have developed rapidly. Before this country was formed into a nation-state with cultural institutions, ethnic Chinese had undergone literary expressions. Moreover, culture at that time was widely accepted for Malay nations, Java, Balinese, etc. Conversely, many identity challenges and contestation during Dutch colonial, Old Order, and New Order pressed the ethnic Chinese in various ways. In addition, this can be understood as a part of cultural exchange. Hence, Indonesian literature is currently strongly influenced by the contact of Malay and Chinese literature.
\end{abstract}

Keywords: Dutch Colonial, Ethnic Chinese, Indonesian Literature, New Order, Old Order

Abstrak: Sejarah dan kemajuan sastra Indonesia menjadi bukti otentik bagi etnis Tionghoa. Keduanya dapat memberikan pengaruh terhadap sastra Indonesia kontemporer secara luas. Hal ini dapat dilihat dari sejarah literasi Indonesia, romansa, cerita silat, dan gaya penulisan sastra Cina yang masih digunakan hingga saat ini. Hal ini menunjukkan bagaimana pendidikan etnis Tionghoa dan Hibrid (Melayu-Tionghoa) di Indonesia berkembang pesat. Sebelum negara ini dibentuk menjadi negara-bangsa dengan institusi budaya, etnis Tionghoa telah mengalami ekspresi sastra. Lebih lanjut, budaya saat itu diterima secara luas oleh bangsa Melayu, Jawa, Bali, dll. Sebaliknya, banyak tantangan dan kontestasi identitas pada masa penjajahan Belanda, Orde Lama, dan Orde Baru menekan etnis Tionghoa dengan berbagai cara. Selain itu, ini dapat dipahami sebagai bagian dari pertukaran budaya. Oleh karena itu, sastra Indonesia saat ini sangat dipengaruhi oleh pertemuan sastra Melayu dan Cina.

Kata Kunci: Penjajahan Belanda, Etnis Cina, Sastra Indonesia, Orde Baru, Orde Lama

\section{INTRODUCTION}

Literature in Indonesia has found a way to survive over time. It can be seen through many literary festivals and awards for writers, such as the annual Kusala Literary Award. Moreover, there are also many literature book publishers for each genre with various readers. From this phenomenon, Indonesian literature can be re-traced. In addition, it is very close to historical evidence, the debate of history, identity, and politics. The literature's identity and politics are complex and complicated, especially in Chinese, Chinese-Malay, or Hybrid (Malay-Chinese) in Indonesia. 
The role of the Hybrid (Malay-Chinese) group in Indonesia during the Dutch colonial era was to shape its identity through literary writings (Sutrisno, 2017). Many translations of novels were from China, and some were inspired by China dynasties, such as Cerita silat or martial arts and romance stories. Primarily, this shows that Hybrid in colonial Indonesia is able to fight for their identity despite the ups and downs of relations between natives and colonials in this country. Generally, many of the Hybrid writings use the Malay language very well. However, the literary tradition itself follows the trend from Europe, with the Dutch being one of the influences. The Dutch colonial period of Chinese stories was famous until after Dutch colonialism. Not only in literature, but Hybrid also established various newspapers, such as Bintang Barat, Dinihari, Siang Po, and so on (Sutrisno, 2017).

It is interesting to look deeper into the role of literacy in Hybrid style in Indonesian writers. Claudine Simon reviewed Lim Kim Hok's novel Tjhit Liap Seng or Bintang Tudjuh (Seven Stars). It was published in 1886-1887 as the first modern Malay language novel and got a good response from Monique ZainiLajoubert, who saw Lim Kim Hok's literary work, the Poem of Siti Akbari (1885) (Suryadinata, 1996). It explained that the role of literature in Malay identity for Hybrid is enormous. In contemporary Indonesian literature, there is a literary magazine, such as Horison. Furthermore, in 1920-1930, literary magazines, such as Penghidoepan and Tjerita Roman, were valuable to a literary movement in Indonesia.

Cerita silat (Martial arts story) from Kho Ping Kho was very popular in the classic tale of Indonesia. Afterwards, many Indonesian writers wrote Cerita silat, such as the story of Wiro Sableng, and so on. The Hybrid literary style was the Tionghoa Malay style. In that style, there was an awareness of identity at the beginning of the 20th century with the founding of the Tiong Hoa Hwee Koan (THHK) school and the Holladsch-Chinese School (HCS), which encouraged the birth of Malay Chinese literature (Suryadinata, 1996). What can be seen in Malay Chinese literature are a didactic style in writing and part of the social ideology of Confucianism, literature as an educational path, and entertainment. Their literary writings tend to be informative with events that occur. Cerita silat and romances stories increased and became part of reading in Indonesia national newspapers, gradually Hybrid literacy effect was marginalized by the many literary traditions between LEKRA (Lembaga Kebudayaan Rakyat) and MANIKEBU (Manifestasi Kebudayaan). The loss of Peranakan literature became blurred by the cultural integration after and before the independence of Indonesia. However, Hybrid literature gave birth to Malay literary traditions that connect us to history and the developing narrative of broader literature in Indonesia. The Malay-Chinese center is included in the great history of Malay literature, including Indonesia.

In contemporary literature writers such as Pramoedya Ananta Toer, there was a conflict in writing of battle scenes visible in his literary works. This way of writing is examined deeper in more recent literature. In that case, Eka Kurniawan's novel titled "Seperti Dendam, Rindu Harus Dibayar Tuntas" (Like Revenge, Longing Must Be Paid Completely) shows the conflict that occurred in Ajo Kawir, who fought to vent his frustration. The way of writing battles and silat is similar to the writings of Kho Ping Kho and his other novel, such as "Lelaki 
Harimau" (Man Tiger). Moreover, Seno Gumira Ajidharma, in adapting silat stories into comics and short stories, becomes part of Indonesian literature.

\section{METHODS}

This study utilized qualitative method in analyzing the impact of Chinese literature within Indonesian literary field. The data consisted of previous studies in the form of articles and books that discussed the historical trajectory of Chinese literature in Indonesia, especially the ones came from Lim Kim Hok and Kho Ping Ho. These data were then divided into three sections for discussion, namely Chinese Literary History, Literature and Discrimination, and the future of Chinese-Malay Literature in Indonesia.

\section{DISCUSSION}

\section{Chinese Literary History}

Literature, in a broad context, is about writing and publication, the culture and identity that develops, and the exchanges within it. In Indonesia, Chinese ethnic overgrew their culture because cultural offerings between Chinese and Malays met through literature. Malay is an eastern nation with an artistic and literacy style such as sagas, rhymes, and poetry. Meanwhile, ethnic Chinese who came to Nusantara write stories and romances. Most stories are closely related to silat stories. Malay people are no strangers to silat and romance stories. Therefore, here, as Claudine Simon said in his book, is the occurrence of cultural exchange through literature and art. Through litigation search, Claudine Simone categorizes significant works such as Sanguo Zhi Yanyi (The Romance of the Three Kingdoms), Xiyou Ji (The Pilgrimage to the West), Jingu Qiguan (Wonders New and Old), Shuihu Zhuan (The Water Margin), (Salmon, 2013) and so on. The great works from China were translated, interpreted, followed by other fiction, stories, and various translations.

Specifically, in Chinese stories that are translated into Malay-Indonesian, there are translations of Chinese religious and didactic works entitled Xue Rengui Zheng in 1859 in Javanese manuscripts (Salmon, 2013). Meanwhile, it cannot be traced to the time when the Chinese story was first translated into Malay. Whereas in Batavia (now: Jakarta), Chinese fiction novels were translated in 1882. The development of Chinese stories became wider, and those stories were translated into Javanese in 1913 and Balinese at the end of the 19th century. It illustrates that Chinese literature gradually entered Nusantara, following market developments, and readers whose readers from Chinese Literature were from Peranakan, Totok, and other Chinese ethnic groups and Malay natives SumatraMalaysia-Belitung-Sambas, Java, Makassar, and Bali.

Indonesian references which discussed ethnic Chinese literary works that portray Chinese ideology and identity openly are limited. Historically, in the colonial era, this was not a big problem. In newspapers, Chinese literature in the form of silat stories was always printed locally. In addition, there was ethnic Chinese nationalism which was aware and organized to establish Tion Hwa Hwe Kuan (THHK). Besides, there was also a different treatment to Chinese traditional education which could be seen by the establishment of Hollandch Chinese School (HCS) (Anoegrajekti, 2016). Suryadinata emphasizes how the 19th Century 
Chinese empire gave moral support and exceptional attention to ethnic Chinese migrants in Southeast Asia (Suryadinata, 1999). However, this is not surprising for China, which saw an advancement in its literary movement. In addition, not always the aim of literacy is the introduction of ethnic Chinese culture. In the 1920s, the translation of Chinese stories into non-Chinese languages was very favorable (Salmon, 2013), which became the most enjoyed by newspaper readers and readers of stencils books (Buku-Buku Stensil).

Many variants cannot explain the distribution of Chinese literature to Korea and Japan, as described by Claudine Salmon. However, in Indonesia, the spread of Chinese literature can be traced through the Fujian area. Salmon explained that all Chinese novels in Semarang originated in the 19th century and mainly originated in Fujian, found in 1828 published by the Ping Min Quanzhuan, better known as "Complete Account of the Pacification " Fujian" (Salmon, 2013). It emphasized the relationship between China and Nusantara in literacy. It had been going on for a long time and was well accepted as part of a global trade culture and literary movement, at that time.

\section{Literature and Discrimination}

However, Peranakan literature in colorful history does not mean that Peranakan literature runs without barriers to discrimination and the marginalization of most Malays and Javanese. When the writers wrote Peranakan literature, their writing was not considered part of qualified literature. In other words, brand writing about silat stories and Chinese romance was deemed inappropriate for occupying academic classes because of the low class position of Malay language. Pamela Allen (2003) expressed it as part of the discrimination of the Malay language used by Hybrid. It was Malay low-class (Melayu Rendah, laag Maleisch), Malay Market (Melayu Pasar, Passer Maleisch), or Jumble Malay (Melayu ceracau, Brabbel Maleisch). Hence, it was ignored by Indonesian literary critics. Moreover, it was not published by significant publishers, such as Balai Pustaka and other Malay-Indonesia literature.

Literature and politics of prestige Malay language became an exclusive strategy of how the publisher, Balai Pustaka (Volkslectuur), became problematic because it placed literature as part of politics and was exclusive only to Indonesian Malay (Swantoro, 2002). Moreover, Balai Pustaka was considered a publisher of great Indonesian Malay literary works such as Achdiat K Miharja, Marah Rusli, AA Navis, Sutan Takdir Alisjahbana, Abdoel Moeis, and so on. Ironically, when talking about the rise of Indonesia literature, the discussion always leads to Siti Nurbaya, Salah Asuhan, Perawan di Sarang Penyamun and so forth. Practically, literature, language, and identity had a strong influence. It seems as if Chinese identity in literature entered the new era of Indonesia, leading up to independence and after Indonesian independence became exclusively for the natives.

When Chinese literature was marginalized from Indonesian literature, interestingly, Pramoedya Ananta Toer raised the characteristics of the Chinese people in the role of strong-willed and humble (Red: Tetralogi Pulau Buru). In the Pramoedya novel, Hoakiau di Indonesia shows how the Indonesian government discriminated against ethnic Chinese. Subsequently, Chinese-Malay identity was 
determined against and raised through literature or not far from the narrative of literature.

Hybrid literature then moved up and down in Indonesia. It became worse when President Suharto imposed a presidential decree in 1967, limiting ChineseIndonesian space. It automatically removed the 'Indonesian Chinese literature' category, which impacted the ban on Chinese writing and not much more Hybrid writings in the popular newspaper (Allen, 2003). The government propaganda was that the Hybrid Literature was considered as communist writing to spread the communism ideas (Suryadinata, 1996).

In the era of reformation (era reformasi), Indonesian Chinese literature was re-established, initiated by Wilson Tjadinegara and Taufiq Ismail founded the 'Perhimpunan Seni Budaya Ibu Pertiwi' which later became the forerunner of 'Perhimpunan Penulis Tionghoa Indonesia' moving during 1998-1999. Characteristics of Chinese literature, as understood by Al-Fayyadl (2002), is divided on two things: the object of study thematic characterizes Chinese literature, and the form of the syntactic structure of literary works. Thus, reading Hybrid literature would be interesting once the character and identity of the Chinese community show. Moreover, the kinship relationship of Chinese showed by family ties also ads it up (as there is in principle teachings of Confucianism), It is the most prominent. Meanwhile, the others are economic problems and bankruptcy, such as prose thematic "Dengan Duwa Cent Jadi Kaya " (Became Rich With Two Cents) written by Thio Tjin Boen in 1920.

\section{The Future of Chinese-Malay Literature}

National literary forms in Indonesia Y.B Mangunwijaya, Ahmad Tohari, Kuntowijoyo, and others are often regarded as examples of 'high quality literature' (Sastra yang Bagus). That is a problematic issue in Indonesian literature. Many Indonesian writers approach that classifying literary genres is the wrong side of many literature progression. In an interview with Daus AR to Eka Kurniawan (2015), it appears as a form of literary favoritism in Indonesia. Eka Kurniawan explained that literary writings are only a few academic schools and genres as literary favouritism in his interview. Eka Kurniawan in Literature writing is widely renowned with naughty language. Moreover, in his interview, he also said this, "... For me, it is not a criminal act to place Kho Ping Hoo, Abdullah Harahap and Pramodya above other Indonesian writers." (Kurniawan, 2015).

It appears that Peranakan literature places itself closer to the familiar people, and its readers are ordinary people. In some of these writers the Post-war Kung Fu novels in Indonesia - (A Preliminary Survey): Oey Kim Tiang, Boe Beng Tjoe, Chung Sin, Gan KL (Gan Kok Liang), Tjan Ing Djiu (Tjan ID, Can) Asmaraman S. Kho Ping Hoo (Suryadinata: 1996) is evident how the stories are stories that occur among the grassroots. However, it is not only that. Based on the observation of Eka Kurniawan (2006), literature written by Kho Ping Hoo and other Hybrid writers gave reasoning to the history of the archipelago in his stories. History is an important element in forming silat stories, such as in the novel Satria Gunung Kidul, Sepasang Garuda Putih, Banjir Darah di Borobudur, Kidung Senja in Mataram, etc. Kho Ping Hoo illustrates historical gaps in the 
Javanese kingdoms to rural folklore stories. He even has continued to write the stories of criminals.

Silat stories were written by Peranakan or Chinese-Malay writers as pioneers in shaping language patterns and even Indonesian literature. In the end, many Indonesian writers now adopt the same writing style and story setting as the writings of the many editions of silat and romance stories by Peranakan writers. In the short stories Seno Gumira Adjidarma, besides being influenced by SH. Mintardja, and Kho Ping Hoo, the writing style can be seen in the Seno Gumira Adjidarma novel entitled Nagabumi I: Jurus Tanpa Bentuk. From that kind of literature, Eka Kurniawan and Seno Gumira Adjidarma seemed to disregard the preparation of the literary canons. it is considered obsolete and is no longer an exciting discussion, because in a stream of more progressive stories, all is to be regarded as literary writing. Not only martial arts stories, comics and freelance writing can also be considered literary.

In the book Kho Ping Hoo and Indonesia, Seno Gumira Adjidarma (Ardus, 2012) at least make three things to mark the first literary essays in Cerita Silat Kho Ping Hoo, 1) The story Silat Indonesian language despite taking the background of China, still regarded as Indonesian literature, 2) Kho Ping Hoo is a legend story writer Indonesian martial arts and romance, 3) no longer relevant to talk about what is literature and what non-literary.

Indeed, Chinese and Malay writers in Indonesia are not mentioned in the influential Indonesian literary books. However, it does fall into literary politics that often occurs over the political interests and privileges of the Indonesian majority. To re-elevate Chinese identity in Indonesia, which has been merged, it can be referred to through literature which is a treasure of Indonesian literature.

From what was written above, it appears that the development of Indonesian literature will find a new way of seeing the uniqueness of the many editions of Chinese silat and Roman stories in Indonesia. Perhaps, literature and its period of popularity with stencils and silat stories are over, and it is hard to find back Peranakans who write silat and romance stories. However, it does not mean the contribution and role of martial arts novels of writers Peranakan ignored in contemporary literary criticism and methods of writing stories and Hybrid highly productive author in writing.

\section{CONCLUSION}

Chinese literature, particularly Hybrid, faces the influence and presence of the tides, or even the 'disappearance' as a narrative of Indonesian literature that should be returned as a challenge. In addition, the politics of literature shows that literature is not neutral and does not favor one class, race, or language. SARA (Ethnic, Race, and Religion) is also contained in the literature. It indicates the nature of discrimination and Indonesian literature initially exclusively favoring the kind of language that is considered a prestige language and the kind of writing that is regarded as a prestige language to have a good standard. While it is, on the contrary, Peranakan author's writings, and the Chinese-Malay deemed not to have criteria that were created in the literary canons.

Gradually, Hybrid literature has given a spotlight because the writings were 'down to earth' and famous in its time. It is considered reading 
entertainment classes of society who do not have access to libraries and books of literature published by Balai Pustaka. In other words, the writings of the authors Peranakan sold on the market like newspapers and crossword puzzles (Teka Teki Silang). With many publications and editions that number in the hundreds, Peranakan literature in Indonesia has become an inevitable phenomenon.

The emergence of awareness is to raise Hybrid literature was formed for several purposes. The first one is as a form of Indonesian literary history in a practical and common in society. It considered Indonesian literary history during the dutch colonial era, Old Order, New Order, until the reform era. It is all very close and has a connection with Hybrid literature. The second one is to understand the identity of ethnic Chinese in Indonesia in Indonesian history. Third, as a way of understanding literature, Peranakan provides an enormous role in consumer readers' storybooks in Indonesia.

\section{REFERENCES}

Al-Fayyadl, M. (2002). “Sastra Tionghoa dan Prasangka 'Politik Identitas.'” Availableat:http://web.budaya-tionghoa.net/index.php/item/1147sastra-tionghoa-dan-prasangka-politik-identitas.

Allen, P. (2003). Sastra Diaspora?: Suara-suara Tionghoa Baru di Indoensia. Antropologi Indonesia, 71. https://doi/org/10.7454/ai.v0i71.3469

Anoegrajekti, N. (Ed.). (2016). Jejak Langkah Perubahan Dari Using Sampai Indonesia. Penerbit Ombak.

Ardus. M. Sawega. (2012). Kho Ping Hoo \& Indonesia-Seniman dan Karyanya. Balai Soedjatmoko.

Kurniawan, E. (2006). Sejarah dalam Cerita Silat Kho Ping Hoo' (Kompas).

Kurniawan, E. (2015). Tanya-Jawab: Pengaruh Sastrawan Indonesia (F. D. AR, Interviewer) [Interview]. https://ekakurniawan.com/journal/tanyajawab-pengaruh-sastrawan-indonesia-6833.php.

Salmon, C. (2013). Literary Migrations: Traditional Chinese Fiction in Asia (17th20th Centuries). Institute of Southeast Asian Studies.

Suryadinata, L. (1996). Sastra Peranakan Tionghoa Indonesia. Grasindo.

Suryadinata, L. (1999). Etnis Tionghoa dan Pembangunan Bangsa. LP3ES.

Sutrisno, E. (2017). Moral is political Notions of ideal citizenship in Lie Kim Hok's Hikajat Khonghoetjoe. Wacana, 18(1), 183.

https://doi.org/10.17510/wacana.v18i1.577

Swantoro, P. (2002). Dari Buku ke Buku: Sambing-Menyambung Menjadi Satu. Gramedia. 